\title{
Journal of Marketing Management
}

\section{Do demographics have an impact on country of origin effects?}

\section{Anja Schaefer}

To cite this article: Anja Schaefer (1997) Do demographics have an impact on country of origin effects?, Journal of Marketing Management, 13:8, 813-834, DOI: 10.1080/0267257X.1997.9964513

To link to this article: http://dx.doi.org/10.1080/0267257X.1997.9964513

\section{Published online: 06 May 2010.}

\section{Submit your article to this journal $\sqsubset$}

山 Article views: 98

Q View related articles $\sqsubset$

4 Citing articles: 10 View citing articles ๘ 


\title{
Anja Schaefer \\ King's College London, Campden Hill Road, \\ Do Demographics Have an Impact on Country of Origin Effects?
} London W8 $7 A H$

\begin{abstract}
The article discusses the potential impact of consumers' age, socioeconomic group, and sex on the magnitude of country of origin effects for lager and sparkling wine and presents the results of an empirical study into the subject. It is found that older consumers show stronger country of origin effects, which may be due to a generally stronger reliance of older people on broader mental categories, in order to compensate for a decrease in working memory. Socio-economic groups $A B$ are found to show stronger country of origin effects for sparkling wine, whereas socio-economic groups $C 1 C 2$ show stronger country of origin effects for lager. This may be related to relative differences in consumption patterns and expertise for the studied products between the two groups. Sex is not found to have any impact on the magnitude of country of origin effects in this study.
\end{abstract}

\section{Introduction}

Does country of origin have an impact on consumers' evaluations of a product? This question has been of interest to researchers since the 1960s. Numerous studies have shown that consumers are able to distinguish between product offerings on the basis of country of origin (e.g. Schooler 1965; Reierson 1966; Nagashima 1970; Gaedecke 1973; Bannister and Saunders 1978; and many more).

However, consumers' perceptions of products made in different countries of origin seem to vary depending on a number of contingencies, such as the nationality of the consumers (Nagashima 1970, 1977; Cattin et al. 1982; Papadopoulos et al 1991), the product category and attributes under consideration (Etzel and Walker 1974; Halfhill 1980; Kaynak and Cavusgil 1983; Roth and Romeo 1992), and consumer demographics (e.g. Schooler 1971; Dornoff et al. 1974; Morganoski and Lazarde 1987).

Criticism of early research in the area, as voiced in a seminal article by Bilkey and Nes (1982), focused particularly on the fact that studies that gave respondents only a single product information cue, i.e. country of origin, were unrealistic and likely to overestimate any effects that country of origin might have on product evaluations and purchase decisions.

In order to separate between consumers' response to country of origin when they are presented with that cue only, and their response when presented with country of origin as one of several cues, it is useful to distinguish between two related but different concepts: product-country images and country of origin effects. Productcountry image can be defined as the beliefs that consumers hold about products, of one product class, made in a specific country. In contrast, country of origin effect can be defined as the extent to which such product-country images affect consumers' evaluations and purchase behaviour with regard to these products. 
The existence of differential product-country images is a necessary condition for country of origin effects to emerge but it is not in itself a sufficient condition. It seems perfectly possible for consumers to believe that products from different countries differ from each other without attaching too much importance to these beliefs when actually evaluating a product or making a purchase decision. Depending on the situation, other factors may be more important than product-country images when it comes to making a purchase.

This has been recognised by much of the research conducted since the publication of Bilkey and Nes's (1982) criticism of the early single-cue studies. Since then a number of researchers have looked at country of origin effects in multi-cue studies. These studies usually found that country of origin still exerted an influence on product evaluations even when other product information is available. However, the magnitude of these country of origin effects seems to vary quite considerably between the different studies. While Thorelli et al. (1989) concluded that country of origin only had a relatively minor influence on product evaluations, other studies (e.g. Tse and Gorn 1990; Ettenson 1993; Nes and Bilkey 1993; Okechuku 1994) found it to be a fairly important cue, even though its importance still varied anywhere between first and third or fourth place of all cues used.

A few authors have discussed possible determinants of the magnitude of country of origin effects. The usefulness of any product information cue is thought to depend on its predictive and confidence value (Cox 1962). Schellinck (1983) supposes that country of origin is generally of low predictive but high confidence value. In an empirical study he found that consumers tended to use such cues only when there was considerable time constraint, normally preferring cues with both high predictive and high confidence value or, if these were deemed insufficient, cues with high predictive and low confidence value.

Eroglu and Machleit (1989) argue that the predictive value of country of origin can vary depending on (1) product involvement, (2) technical complexity of the product, (3) consumer experience, and (4) consumers' ability to perceive inter-brand differences. Johansson (1989) argues that both predictive and confidence value of the country of origin cue can vary depending on circumstances. According to Johansson the predictive value of the cue depends on (1) the variability of products between countries and (2) the variability of products within a country. He argues that the confidence value of country of origin depends on (1) consumers' level of familiarity with a country's products and (2) the reliability of country identification (which can be affected by factors such as off-shore production, outsourcing of component parts, etc).

Apart from these general discussions there seems to be a curious scarcity of research into factors that might influence the predictive and confidence value of the country of origin cue and thus the magnitude of any country of origin effects. A few empirical studies have looked into the potential impact of consumer knowledge on country of origin effects (Han 1989; Cordell 1992; Akaah and Yaprak 1993; Maheswaran 1994; Schaefer 1997) but there seems to have been little systematic effort to determine further intervening factors. This seems all the more surprising considering that a number of factors, such as demographics, personality, situational variables, etc are thought to be influential in consumer behaviour in general, and that early studies found that consumer demographics and personality had some influence on product-country images. 
This article attempts to help to close this gap by examining whether selected consumer demographics (age, sex, socio-economic group) can have an impact on the magnitude of country of origin effects in the evaluation of two fast-moving consumer goods (FMCGs): lager and sparkling wine. Some demographic variables have been found to influence product-country images in past studies but, to the best of the author's knowledge, no study so far has looked at any impact of such variables on the magnitude of country of origin effects. There are, however, good reasons to assume that at least some demographics may impact on country of origin effects as well, and such a study seems overdue.

The two products were chosen for a number of reasons: (1) most research in this area has dealt with consumer durables, and product-country images and country of origin effects in the area of FMCGs seem to be somewhat under-researched; (2) the UK markets for the two chosen products contain a large number of foreign products; and (3) manufacturer brands feature prominently in both markets, which facilitates a comparison of the magnitude of brand name and country of origin.

\section{Research Hypotheses}

There is little in the country of origin literature to suggest what impact, if any, consumer demographics may have on the magnitude of country of origin effects. There seem to be no previous studies into the impact of demographics on country of origin effects, and the existing literature on demographics and product-country images can give little guidance, as the two concepts are different. Yet some of the wider literature on consumer behaviour and psychology can help to develop relevant hypotheses.

Age

There is some evidence that, as humans grow older, they experience certain cognitive changes. Older people may suffer some loss in working memory (Salthouse 1985, 1991; Wingfield et al. 1988) and appear to be generally slower at a number of tasks, including information processing (Birren et al. 1962; Salthouse 1985; Cole and Balasubramanian 1993). On the other hand, information stored in longterm memory seems to stay relatively stable or even increase with age (Baltes 1987). Older people may therefore be able to draw on their experience in order to compensate for some loss in information processing capacity (Baltes et al. 1984). Indeed, Schaie (1977) suggests that older people enter a stage of cognitive development, termed "re-integrative", where problem-solving is simplified and increasingly carried out with reference to the individual's life experience.

Mental categories, or stereotypes, used to group "things of a kind", are an important part of human cognition and their main purpose seems to be to reduce mental processing effort (Lakoff 1987). It would seem reasonable to assume that an increased reliance on categories stored in long-term memory may be one strategy that can help older people to compensate for a diminished capacity to process new information. 
Furthermore, it has been found that older people employ different categorisation strategies from younger people in so far as they seem to "chunk" information into larger units, i.e. they use fewer but broader categories (Kogan 1974; Cicirelli 1976).

If older people face some loss of working memory and speed, leading to a certain decrease in the ability to process new information, they may face problems in taking in and evaluating information about the intrinsic attributes of individual products. If they try and compensate for this through the increased use of categories they may tend to rely more strongly on extrinsic product cues, such as country of origin, brand name, price, etc. If older adults additionally tend to "chunk" information into fewer but broader categories, they may prefer to rely on broader cues, such as country of origin, rather than narrower ones, such as brand name. Older consumers may therefore show stronger country of origin effects.

H1: Older consumers will show stronger country of origin effects than younger consumers.

Socio-economic Group

Various authors argue that social class and socio-economic group remain valid discriminators between purchasing behaviours (Coleman 1983; O'Brien and Ford 1988) and a recent study by Usunier (1994) suggested that it continues to exert an influence on product-country images. What then are the likely impacts that socioeconomic group may have on the magnitude of country of origin effects?

Based on studies of American consumers, some authors argue that a major difference between social classes lies in their world view. The world view of working class people is thought to be more constricted than that of middle or upper class people. Working class consumers apparently tend to orient themselves in terms of the community rather than the world at large, and might be more conservative (Coleman 1983; Solomon 1994).

There is also some evidence to suggest that consumers of higher socio-economic status may be more experienced with products from a wider range of countries and more likely to experiment due to higher disposable incomes and more foreign travel (O'Brien and Ford 1988; Solomon 1994).

For these reasons early research into the impact of socio-economic group on product-country images expected - and often found - that consumers of lower social status would exhibit more negative attitudes towards products from new or unusual countries of origin. It is, however, less clear how these differences between socio-economic groups may impact on the magnitude of country of origin effects.

Two different hypotheses seem possible, depending on what one assumes the basic function of country of origin in product evaluations to be. If one assumes that country of origin acts as a kind of screening device, whereby consumers use country of origin to decide quickly which products to exclude from their consideration set (M.J. Baker, personal communication) one might expect that consumers with more limited experience of different countries of origin, i.e. possibly consumers of lower socio-economic groups, would be more likely to decide against a larger number of countries of origin and thus show stronger country of origin effects. 
However, if one assumes that country of origin is used actively to help in making decisions about products within the consideration set, the situation may be different. As yet, there is no conclusive evidence regarding the role of consumer knowledge and experience in country of origin effects, but Johansson (1989) argues that a certain amount of product and country knowledge may be useful, if not necessary, in order to use country of origin in product evaluations. Recent findings by Schaefer (1997) suggest that, at least in situations where limited product information is available, consumers with higher levels of product knowledge may be more likely to rely on country of origin than consumers with lower knowledge levels. If one follows this train of thought, consumers with more experience of different countries and of products from different countries of origin, who are likely to be of higher socioeconomic status, may well be better equipped to use country of origin in product evaluations and thus show stronger country of origin effects.

More research into the basic nature of country of origin effects is needed before we can confidently back one or the other of these hypotheses. For the present study a more basic hypothesis has, therefore been adopted:

$\mathrm{H} 2$ : The magnitude of country of origin effects will vary depending on the socio-economic group of the respondents.

Sex

The assumption that sexes differ in their consumption behaviour is widespread and underlies much consumer research, product positioning and advertising strategy, and can be found in most textbooks on consumer behaviour (e.g. Solomon 1994). Fischer and Arnold (1994) distinguish between the three concepts of "sex", "gender identity" and "gender role attitudes". Of these three constructs sex is the one that seems most likely to have an impact on country of origin effects.

"Sex" refers to the biologically based differences between males and females, such as innate differences in abilities or behaviours. Such differences seem to affect only a relatively small set of cognitive abilities and social behaviours, including - apart from verbal, mathematical and visual-spacial ability (Maccoby and Jacklin 1974) and a greater propensity of females to conform to social influence (Hall 1978) differences in information processing.

Sex differences in information processing have been found by a number of studies. One group of researchers found that females engage in more extensive information processing, using all available cues, whereas males are more likely to concentrate on a few, easily available cues and use these as heuristics (Meyers-Levy 1989; MeyersLevy and Maheswaran 1991; Meyers-Levy and Sternthal 1991). The same researchers, however, also found that such differences in processing strategies only surfaced where the situation did not strongly favour one or the other processing strategy. Other research findings suggest that females may be more likely to use interpretative, subjective product information than males, who are more likely to focus exclusively on objective attribute information (Poole 1977; Haas 1979; Darley and Smith 1995).

Such differences in information procession might, depending on the circumstances, impact on the use of country of origin information in product evaluation. If 
males are more likely to use easily accessible cues as heuristics they may be more likely to use country of origin, which is precisely such an easily accessible cue. Following this reasoning males may be expected to show stronger country of origin effects. Country of origin is also in itself normally an objective cue, in so far as a product's origin is mostly clearly stated on the label, although hybrid products may be an exception. This would again suggest that males may use the cue more frequently. However, the stated sex related differences in processing strategies have only been demonstrated in situations that do not strongly encourage one or the other strategy, precisely something that the situation presented to respondents in this study does. Where respondents are presented with two easily accessible, objective cues only both males and females would seem to have little choice but to use these cues. Under these circumstances the stated differences in processing strategies are unlikely to surface and there may be no sex related differences in the magnitude of country of origin effects in this study.

H3: There will be no differences between the sexes in the use of country of origin in product evaluations.

\section{Methodology}

Data for this research was collected mainly through a consumer survey. Prior to the survey, two consumer focus group interviews were held to develop a feel for the markets and the issues involved and to provide input for the development of the questionnaire.

\section{Data Collection and Sample}

Data to test the above hypotheses was collected on the two products, lager and sparkling wine, through a consumer survey, conducted with a convenience sample in various towns and neighbourhoods in Buckinghamshire, Oxfordshire and Northamptonshire, UK, in 1993. A total of 800 questionnaires (400 referring to lager, 400 referring to sparkling wine) were distributed directly to homes in various neighbourhoods, chosen to be fairly heterogeneous and thus, hopefully, to give a relatively broad cross-section of the general population. The questionnaire was accompanied by a covering letter which explained how to fill in the questionnaire and offered a small incentive, and a stamped, addressed envelope.

A total of 100 responses relating to lager and 117 responses relating to sparkling wine were received, resulting in a response rate of $25 \%$ and $29 \%$, respectively. The respondents match published profiles of lager and sparkling wine consumers (Key Note Report 1993; Retail Business 1994) quite well in the distribution of males and females. However, the obtained sample is on average slightly older and of higher socio-economic status than the respective consumer profiles, not an unusual result in self-selecting samples. While this slightly skewed sample may have an impact on the average ratings for the total sample it is not thought to have any great impact on the specific focus of the research, where age, socio-economic group and sex are the 
controlled variables. Correlations between the demographic variables were insignificant (correlation coefficients of 0.017, 0.019 and 0.003 for lager respondents, and $0.059,0.02$ and 0.028 for sparkling wine respondents were found) so that a skewed distribution in one variable is unlikely to have confounded the results concerning the other variables.

\section{Operationalisation of Key Concepts}

In this study a simplified evaluation situation was given, where the available product information was restricted to country of origin and brand name. Respondents were asked to rate products (1) on the basis of both brand name and country of origin (also called "brand ratings" hereafter) and (2) on the basis of country of origin alone (also called "country ratings" hereafter). Ratings were on seven-point semantic-differential scales on the dimensions of "overall quality", "value for money", and "social acceptability/trendiness". The countries of origin included were: Australia, Belgium, Czechoslovakia, Denmark, Germany, The Netherlands and the UK in the questionnaire relating to lager, and Australia, France, Germany, Hungary, Italy and Spain in the questionnaire relating to sparkling wine. Two brands were included from each country, one familiar, the other unfamiliar (invented by the researcher). The questionnaire is reproduced in abbreviated form in the Appendix.

In order to operationalise country of origin effects, ratings on the basis of country of origin alone and ratings on the basis of country of origin and brand name together were correlated (using Spearman's rho) for each country-brand pair across the sample. The degree of correlation was interpreted as an indication of the magnitude of country of origin effects when evaluating a product on the basis of brand name and country of origin.

Respondents were asked to indicate their age as belonging to one of four groups (18-24, 25-34, 35-54 and 55 and above). They were also asked to indicate their sex and to give their occupation or that of the main income earner in the household, whence socio-economic group was derived. The distribution of the respondents according to these variables is shown in Table 1.

The impact of the three demographic variables on product-country images and country of origin effects was measured by breaking up the total sample into subgroups depending on the stated demographic variables. Country of origin effects were then measured separately for each sub-group. Sign tests were used to test whether the magnitude of correlation coefficients between country and brand ratings differed significantly between the demographic sub-groups.

\section{Limitations}

The chosen research approach has certain limitations that need to be borne in mind when making generalisations from the findings.

(1) A convenience sample was used because the sample needed to be restricted to consumers of the two products. Lists of the populations of such consumers are not available and the construction of a probability sample of these consumers 
was therefore impossible. Using a probability sample of the general population would, in this case, probably not have improved the reliability of the results greatly, as a considerable number of the targeted people would have been likely to be non-consumers. Yet, the use of a convenience sample means that more than the usual caution has to be applied in generalising the results.

(2) There was a relatively high non-response rate. This is probably due to a large number of questionnaires having gone to people who were not consumers of the product in question. A further non-response factor may arise because some targeted persons may simply not be interested in the topic. This means that, on the whole, the present study may overestimate country of origin effects slightly. The moderate response rate has also led to relatively small cell sizes in certain areas. In particular, some of the age groups are quite small and the correlation coefficients for these groups may not be very accurate. However, the error is unlikely to be systematic, i.e. to always overestimate or underestimate the true value. When comparing all correlation coefficients across all country-brand pairings such errors are therefore likely to cancel out.

(3) Correlation analysis only gives an indication of association, not causation. Where the brand names were unfamiliar correlations are in all likelihood caused by subjects' reliance on country of origin in evaluations of products, but where the brand name is familiar an opposite effect might also have taken place. This needs to be borne in mind when interpreting the results, although the problems seems difficult to avoid if one wants to look at both familiar and unfamiliar brands.

(4) Only two products were studied. The effects of demographic variables may be quite general and it does not seem unlikely that country of origin effects for other products may be affected in a similar way but further research should be carried out before this can be stated with confidence.

Table 1. Number of respondents in demographic groups

\begin{tabular}{|c|c|c|c|c|}
\hline & \multicolumn{2}{|r|}{ Lager } & \multicolumn{2}{|c|}{ Sparkling Wine } \\
\hline & Sample & Consumer Profilet & Sample & Consumer Profileł \\
\hline \multicolumn{5}{|l|}{ Age: } \\
\hline $18-24$ & $19 \%$ & $23 \%$ & $7 \%$ & $13 \%$ \\
\hline $25-35$ & $34 \%$ & $31 \%$ & $26 \%$ & $20 \%$ \\
\hline $35-54$ & $41 \%$ & $32 \%$ & $49 \%$ & $26 \%(35-49)$ \\
\hline $55+$ & $6 \%$ & $14 \%$ & $17 \%$ & $40 \%(50+)$ \\
\hline NR & & & $2 \%$ & \\
\hline \multicolumn{5}{|c|}{ Socio-economic group: } \\
\hline$A B$ & $47 \%$ & $20 \%$ & $36 \%$ & $18 \%$ \\
\hline $\mathrm{C} 1 \mathrm{C} 2$ & $49 \%$ & $54 \%$ & $48 \%$ & $52 \%$ \\
\hline $\mathrm{DE}$ & $3 \%$ & $26 \%$ & $9 \%$ & $30 \%$ \\
\hline NR & $1 \%$ & & $7 \%$ & \\
\hline \multicolumn{5}{|l|}{ Gender: } \\
\hline Female & $22 \%$ & $32 \%$ & $57 \%$ & $52 \%$ \\
\hline Male & $77 \%$ & $68 \%$ & $39 \%$ & $48 \%$ \\
\hline NR & $1 \%$ & & $4 \%$ & \\
\hline
\end{tabular}

HSource: Key Note Report (1993).

$\ddagger$ Source: Retail Business (1994). 


\section{Results}

In order to place findings regarding the impact of age, sex and socio-economic group into an appropriate context the following paragraphs give a brief summary of some general findings of the study. The scope of this article does not allow a detailed presentation or discussion of these findings but the reader is referred to Schaefer (1996) for more detail.

\section{Evidence for Country of Origin Effects}

There is evidence for moderate country of origin effects in the lager data, and for relatively strong country of origin effects in the sparkling wine data. In the lager data there are significant, albeit often relatively weak, correlations between ratings of products on the basis of country of origin alone (see Appendix 1, Question 2) and ratings on the basis of country of origin and brand name together (Appendix 1, Question 1), in about $70 \%$ of all comparisons. For instance, brand and country ratings of Australian lager are relatively stronger correlated, whereas the correlations between brand and country ratings of Dutch lager are mostly so weak as to be almost non-existent.

In the sparkling wine data there are significant correlations between ratings in all cases. These correlations are also typically stronger than in the lager data. The strongest correlations in the sparkling wine data are to be found between brand and country ratings of Hungarian sparkling wine and the weakest correlations are between brand and country ratings of French sparkling wine, but even they are highly significant. Table 2 shows the correlations between all pairs of ratings.

\section{The Impact of Age, Sex and Socio-economic Group on Product-country Images}

Contrary to what might be expected, the selected demographic variables seem to have only relatively minor effects on product-country images, i.e. respondents' ratings of products on the basis of country of origin alone. This was tested by comparing the ratings given to a product from a particular country by respondents in one demographics sub-group with the ratings given by the other sub-groups, using Wilcoxon-Mann-Whitney tests. The ratings for a few countries of origin show significant differences between age groups. In the ratings of lager, younger respondents seem to favour countries of origin that have been introduced in the UK market relatively recently, such as Australia, whereas older respondents show a slight preference for more established countries of origin, such as Denmark. However, this finding is not repeated in the sparkling wine data.

A few product-country images also show significant differences depending on the socio-economic group of the respondents. There is some evidence that respondents of higher socio-economic groups rate products from countries of origin that have been newly introduced into the UK market more highly, whereas respondents of lower socio-economic groups seem to favour traditional countries of origin. This applies to both lager and sparkling wine. 
There are virtually no differences between sexes in their ratings of the various countries of origin. The only exception is that females seem to rate Italian sparkling wine more favourably than males.

All in all, there seems to be only a relatively minor impact of the selected demographics on product-country images, which is in contrast with the findings of many earlier studies into this issue, although it is more in line with findings by Usunier (1994). Perhaps the generally greater exposure of all groups in society to information on foreign countries and products made in a variety of countries of origin has led to a homogenisation of attitudes in this respect. This question would, however, merit a separate study.

\section{The Impact of Respondent Age on Country of Origin Effects}

While there only seems to be a minor impact of age, sex and socio-economic group on product-country images it does not automatically follow that there is no such impact on the magnitude of country of origin effects.

Table 2. Evidence for country of origin effect

\begin{tabular}{|c|c|c|c|c|c|}
\hline Country & & Brand & $\begin{array}{l}\text { Ratings of } \\
\text { product qualityt }\end{array}$ & $\begin{array}{l}\text { Ratings of } \\
\text { value for moneyt }\end{array}$ & $\begin{array}{l}\text { Ratings of } \\
\text { trendiness/social } \\
\text { acceptabilityt }\end{array}$ \\
\hline \multicolumn{6}{|l|}{ Lager } \\
\hline Australia & $x$ & Foster's & $0.772 f_{i}^{*}$ & $0.555^{*}$ & $0 \cdot 647^{*}$ \\
\hline Australia & $x$ & Jonstons & $0 \cdot 167$ & 0.051 & 0.048 \\
\hline Belgium & $x$ & Stella Artois & $0.315^{*}$ & $0.194^{*}$ & $0.344^{*}$ \\
\hline Belgium & $x$ & Bouviers & $0.441^{*}$ & $0.182^{*}$ & 0.186 \\
\hline Czechosl. & $x$ & Budvar & $0.691^{*}$ & $0.529^{*}$ & $0.474^{*}$ \\
\hline Czechosl. & $x$ & Karlovy Vary & $0.67^{*}$ & $0.387^{*}$ & $0.58^{*}$ \\
\hline Denmark & $x$ & Carlsberg & $0.545^{*}$ & $0.376^{*}$ & $0 \cdot 383^{*}$ \\
\hline Denmark & $x$ & Tjaelleberg & $0.3^{*}$ & $0.32^{*}$ & $0.328^{*}$ \\
\hline Germany & $x$ & Becks & $0.225^{*}$ & $0.504^{*}$ & 0.158 \\
\hline Germany & $x$ & Schneider & $0.245^{*}$ & $0 \cdot 191$ & 0.063 \\
\hline Netherlands & $x$ & Heineken & 0.042 & $0 \cdot 116$ & $0.182^{*}$ \\
\hline Netherlands & $x$ & Vandemeers & 0.178 & 0.025 & 0.076 \\
\hline UK & $x$ & Carling Black Label & $0.717^{*}$ & $0.52^{*}$ & $0.545^{*}$ \\
\hline UK & $x$ & Smith's & $0.436^{*}$ & $0.283^{*}$ & $0.464^{*}$ \\
\hline \multicolumn{6}{|l|}{ Sparkling wine } \\
\hline Australia & $x$ & Seaview & $0.676^{*}$ & $0.7^{*}$ & $0.694^{*}$ \\
\hline Australia & $x$ & Selkins & $0.594^{*}$ & $0.488^{*}$ & $0.677^{*}$ \\
\hline France & $x$ & Veuve du Vernay & $0.477^{*}$ & $0.319^{*}$ & $0416^{*}$ \\
\hline France & $x$ & Fabier & $0.425^{*}$ & $0 \cdot 41^{*}$ & $0-339 *$ \\
\hline Germany & $x$ & Henkell Trocken & $0.422^{*}$ & $0.587^{*}$ & $0.548^{*}$ \\
\hline Germany & $x$ & Gerber & $0.431^{*}$ & $0.508^{*}$ & $0.422^{*}$ \\
\hline Hungary & $x$ & Magyarska & $0.676^{*}$ & $0.609 *$ & $0.696^{*}$ \\
\hline Italy & $x$ & Asti Spum. Martini & $0.634^{*}$ & $0.501^{*}$ & $0.436^{*}$ \\
\hline Italy & $x$ & Francini & $0 \cdot 515^{*}$ & $0.472^{*}$ & $0.468^{*}$ \\
\hline Spain & $x$ & Freixenet & $0.379 *$ & $0.658^{*}$ & $0.421^{*}$ \\
\hline Spain & $x$ & Monsanta & $0.725^{*}$ & $0.521^{*}$ & $0.476^{*}$ \\
\hline
\end{tabular}

Spearman's rank correlation coefficient, $p$, between product ratings on the basis of country of origin and brand name and ratings on the basis of country of origin alone.

tFigures given are the correlation coefficients between ratings.

†This figure means that the ratings by all respondents of the quality of the brand Foster's, produce of Australia (Q1) and the quality of lager produced in Australia in general (Q2), showed a correlation coefficient of 0.772 , which is significant at the $5 \%$ confidence level.

$*=$ correlation is significant at the $5 \%$ confidence level. 
Table 3 summarises the results regarding the impact of age on country of origin effects. In the lager data there are, on the whole, stronger correlations between brand and country ratings of respondents in the age group 35-54 than between the ratings of 18-24 year old respondents and of 25-34 year old respondents. This is true for both familiar and unfamiliar brand names. While these differences are not necessarily very large, sign tests found them to be significant, mostly at the $5 \%$ level. Where the brand names were familiar, brand and country ratings by respondents of 55 years or more were also significantly more strongly correlated than ratings by respondents in age groups 18-24 and 25-34. Not enough respondents in age group $55+$ rated stimuli involving unfamiliar brand names to allow an analysis of these.

Looking at the sparkling wine data in Table 3 , brand and country ratings by respondents in age group $55+$ are significantly more strongly. correlated than the same ratings by both 18-24 and 25-34 year olds. This is, however, only true where the brand name - country of origin stimulus (Question 1) contained an unfamiliar brand name. The other age groups do not differ significantly from each other in the strength of correlation between their brand and country ratings.

These findings suggest that older consumers may show stronger country of origin effects than younger consumers. This seems to be particularly the case for consumers of lager, less so for consumers of sparkling wine. $\mathrm{H} 1$ thus finds fairly strong support in the lager data and moderate support in the sparkling wine data.

\section{The Impact of Socio-economic Group on Country of Origin Effects}

The findings relating to the impact of socio-economic group on country of origin effects are summarised in Table 4 . In the lager data, the brand and country ratings by respondents in socio-economic groups $\mathrm{C} 1 \mathrm{C} 2$ are, on the whole, more strongly correlated than the ratings by respondents in socio-economic groups $\mathrm{AB}$. This result is highly significant where the product stimulus contains unfamiliar brand names and significant at the $10 \%$ confidence level where the product stimulus contains unfamiliar brand names. This suggests that consumers of socio-economic groups $\mathrm{C} 1 \mathrm{C} 2$ rely more heavily on country of origin when evaluating lagers than do consumers of socio-economic groups AB.

In the sparkling wine data the opposite effect appears. Where the brand names are familiar, brand and country ratings by respondents in socio-economic groups $A B$ are significantly more strongly correlated than the ratings by respondents in socioeconomic groups $\mathrm{C} 1 \mathrm{C} 2$. Where the brand names are unfamiliar the ratings by socioeconomic groups $\mathrm{AB}$ are also more strongly correlated than the ratings by socioeconomic groups DE. These are the only significant socio-economic group-related differences in country of origin effects in the sparkling wine data.

This suggests that, when evaluating lager, respondents of socio-economic groups $\mathrm{C} 1 \mathrm{C} 2$ tend to rely more on country of origin than $\mathrm{AB}$ respondents, particularly if the brand name is unfamiliar. Unfortunately, as there is insufficient data to make a comparison with socio-economic groups $\mathrm{DE}$ in the evaluation of lager, the present data can give no indication whether this means that consumers of lower socioeconomic groups generally show stronger country of origin effects than consumers of higher socio-economic groups or whether groups $\mathrm{C} 1 \mathrm{C} 2$ in particular show 
Table 3. The impact of age on country of origin effects: correlations between country and brand ratings depending on respondent age

\begin{tabular}{|c|c|c|c|c|c|c|c|c|c|c|c|c|}
\hline \multirow[b]{3}{*}{ Country $\times$ Brand } & \multicolumn{12}{|c|}{ Age groupt } \\
\hline & \multicolumn{3}{|c|}{$18-24$} & \multicolumn{3}{|c|}{$25-34$} & \multicolumn{3}{|c|}{$35-54$} & \multicolumn{3}{|c|}{$55+$} \\
\hline & Qual. & Val. & Acc. & Qual. & Val. & Acc. & Qual. & Val. & Acc. & Qual. & Val. & Acc. \\
\hline \multicolumn{13}{|l|}{$\overrightarrow{\text { Lager }}$} \\
\hline Aus $\times$ Foster's & 0.836 & 0.668 & 0.871 & 0.629 & 0.499 & 0.545 & 0.823 & 0.57 & 0.56 & 0.891 & 0.735 & 0.803 \\
\hline Aus $\times$ Johnston's & 0.018 & -0.259 & 0.19 & 0.151 & 0.109 & -0.075 & 0.247 & 0.108 & 0.215 & & & \\
\hline Bel $\times$ Stella Artois & 0.188 & -0.021 & 0.479 & 0.061 & 0.394 & 0.118 & 0.547 & 0.22 & 0.433 & 0.048 & 0.026 & 0.998 \\
\hline Bel $\times$ Bouvier & -0.189 & 0.468 & 0.045 & 0.34 & 0.164 & -0.006 & 0.617 & 0.086 & 0.272 & & & 1 \\
\hline & $\begin{array}{l}0.136 \\
0.308\end{array}$ & 0.24 & 0.628 & 0.598 & $\begin{array}{l}0.406 \\
0.219\end{array}$ & $\begin{array}{l}0.193 \\
0.715\end{array}$ & 0.872 & 0.627 & 0.644 & ! & 1 & 1 \\
\hline $\begin{array}{l}\text { Czech } \times \text { Karlovy Vari } \\
\text { Den } \times \text { Carlsberg }\end{array}$ & $\begin{array}{l}0.308 \\
0.527\end{array}$ & $\begin{array}{r}0.501 \\
-0.347\end{array}$ & $\begin{array}{l}0.343 \\
0.446\end{array}$ & 0.55 & $\begin{array}{l}0.219 \\
0.377\end{array}$ & 0.147 & 0.577 & $\begin{array}{l}0.424 \\
0.498\end{array}$ & $\begin{array}{l}0.593 \\
0.56\end{array}$ & 0.688 & 0.914 & 0.344 \\
\hline Den $\times$ Tjaelleborg & 0.155 & 0.239 & -0.102 & 0.103 & 0.151 & 0.235 & 0.314 & 0.403 & 0.502 & 0.5 & 0.99 & 0.866 \\
\hline Ger $\times$ Becks & 0.417 & 0.37 & 0.364 & 0.28 & 0.267 & 0.034 & 0.22 & 0.546 & 0.082 & 0.577 & 0.371 & 0.451 \\
\hline Ger $\times$ Schneider & 0.135 & $\begin{array}{l}-0.038 \\
-0.221\end{array}$ & $\begin{array}{r}0.267 \\
-0.123\end{array}$ & $\begin{array}{r}0.136 \\
-0.382\end{array}$ & & -0.054 & 0.365 & 0.423 & 0.046 & & & $e_{0.725}$ \\
\hline Neth $\times$ Heineken & 0 & -0.221 & -0.123 & $\begin{array}{r}-0.382 \\
0.198\end{array}$ & -0.056 & -0.202 & 0.425 & 0.488 & 0.48 & 0.152 & 0.25 & 0.725 \\
\hline $\begin{array}{l}\text { Neth } \times \text { Vandemeers } \\
\text { UK } \times \text { Carling Bl.L. }\end{array}$ & $\begin{array}{l}0.022 \\
0.589\end{array}$ & $\begin{array}{l}0.025 \\
0.289\end{array}$ & $\begin{array}{l}0.34 \\
0.5\end{array}$ & $\begin{array}{l}0.198 \\
0.812\end{array}$ & $\begin{array}{l}0.08 \\
0.601\end{array}$ & -0.026 & 0.217 & -0.031 & 0.032 & l 0.973 & $l_{0703}$ & ${ }^{\prime} .813$ \\
\hline $\begin{array}{l}\text { UK X Carling Bt.L. } \\
\text { UK X Smith's }\end{array}$ & 0.605 & 0.42 & 0.469 & 0.204 & -0.006 & 0.504 & $\begin{array}{l}0.683 \\
0.518\end{array}$ & $\begin{array}{l}0.623 \\
0.464\end{array}$ & $\begin{array}{l}0.523 \\
0.494\end{array}$ & & $\begin{array}{l}0.703 \\
1\end{array}$ & 10 \\
\hline \multicolumn{13}{|l|}{ Sparkling wine } \\
\hline Aus $\times$ Seaview & 0.783 & 0.727 & 0.535 & 0.75 & 0.567 & 0.725 & 0.654 & 0.576 & 0.631 & 0.621 & 0.524 & 0.626 \\
\hline Aus $\times$ Selkins & 0.224 & 0.718 & 0.813 & 0.452 & 0.107 & 0.634 & 0.682 & 0.657 & 0.739 & 0.512 & 0.776 & 0.474 \\
\hline Fra $\times$ V.d. Vernay & 0.752 & 0.677 & 0.636 & 0.142 & 0.46 & 0.189 & 0.481 & 0.183 & 0.453 & 0.728 & 0.293 & 0.448 \\
\hline Fra $\times$ Fabier & 0.447 & 0.456 & -0.392 & 0.336 & 0.356 & 0.289 & 0.565 & 0.336 & $0-471$ & 0.529 & 0.694 & 0.309 \\
\hline Ger $\times$ Henkell Tr. & 0.42 & 0.422 & 0.815 & 0.326 & 0.54 & 0.513 & 0.484 & 0.5 & 0.447 & 0.613 & 0.819 & 0.511 \\
\hline Ger $\times$ Gerber & 0.556 & -0.438 & 0.576 & 0.328 & 0.574 & 0.457 & 0.377 & 0.484 & 0.346 & 0.704 & 0.702 & 0.607 \\
\hline Hung Magyarska & 0.946 & 0.433 & 0.341 & 0.49 & 0.497 & 0.815 & 0.707 & 0.68 & 0.617 & 0.625 & 0.698 & 0.78 \\
\hline Italy $\times$ Asti Martini & 0.415 & 0.839 & 0 & 0.493 & 0.398 & 0.281 & 0.516 & 0.543 & 0.555 & 0.539 & 0.565 & 0.436 \\
\hline Italy $\times$ Francini & 0 & 0.319 & 0.424 & 0.348 & 0.359 & 0.293 & 0.594 & 0.52 & 0.504 & 0.628 & 0.498 & 0.535 \\
\hline Spain $\times$ Freixenet & 0.384 & 0.675 & 0.622 & 0.547 & 0.545 & 0.376 & 0.498 & 0.462 & 0.429 & 0.87 & 0.787 & 0.701 \\
\hline Spain $\times$ Monsanta & 0.83 & 0.823 & 0.568 & 0.769 & 0.304 & 0.393 & 0.612 & 0.434 & 0.364 & 0.894 & 0.888 & 0.831 \\
\hline
\end{tabular}

Results of sign tests comparing the strength of correlations between the different age groups

Familiar Brand Names:

Unfamiliar. Brand Names:

Lager

$18-24$ vs $25-34 p=0.6636$

$18-24$ vs $35-54 p=0.0784^{*}$

$18-24$ vs $55+p=0.0075^{* *}$

Sparkling wine

(8-24 vs $25-34 p=03018$

24-34 vs. $35-54 p=0.0072^{* *}$ $24-34$ vs. $\frac{55+p}{55+p}=0.0013$

$18-24$ vs $25-34 p=1.0000$ $18-24$ vs $35-54 p=0.0784$

No comparison with age group $55+$ possible due to insufficient data

24 $35-54 p=0.6072$

$24-34$ vs. $35-54 p=1.0000$ $25-34$ vs $\underline{35-54} p=0.0784$

$18-24$ vs $55+p=1.0000$

$24-34$ vs. $55+p=0.3018$
$24-34$ vs. $55+p=0.3018$

$18-24$ vs $25-34 p=0.4807$ $18-24$ vs $35-54 p=1.0000$
$18-24$ vs $55+p=0.0013^{* 4}$ 
Table 4. The impact of socio-economic group on country of origin effects: correlations between brand and country ratings depending on socioeconomic group

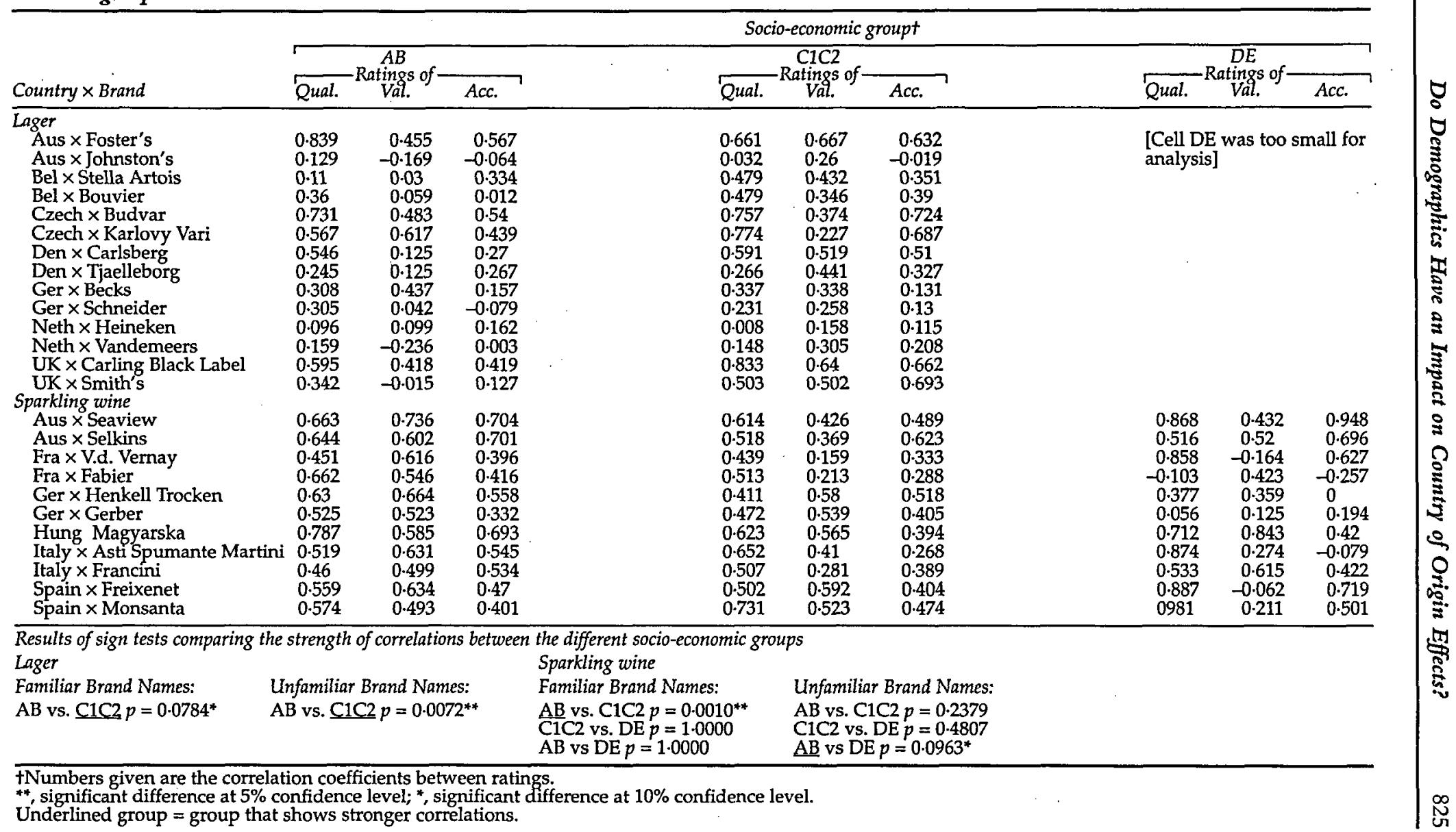


stronger country of origin effects than both higher and lower socio-economic groups. Further research is needed to explore this issue.

In the evaluations of sparkling wine, $A B$ respondents seem to show stronger country of origin effects than respondents of lower socio-economic groups. The familiarity of the brand name appears to have an ambiguous effect in this case and cannot be fully explained at present.

The data suggest that socio-economic group has an impact on the magnitude of country of origin effects and $\mathrm{H} 2$ can be accepted on this basis. However, which socioeconomic groups show stronger country of origin effects may depend on the product.

\section{The Impact of Sex on Country of Origin Effects}

As expected, sex does not appear to have any impact on the magnitude of country of origin effects in this study. Table 5 shows that the correlations of brand and country ratings by the respondents of different sex do not differ in strength. This is

Table 5. The impact of sex on country of origin effects: correlations between brand and country ratings depending on respondents sex

\begin{tabular}{|c|c|c|c|c|c|c|}
\hline Country $\times$ Brand & Qual. & $\begin{array}{c}\text { Female } \\
\text { Val. }\end{array}$ & Acc. & Qual. & $\begin{array}{c}\text { Male } \\
\text { Val. }\end{array}$ & Acc. \\
\hline \multicolumn{7}{|l|}{ Lager } \\
\hline Aus $\times$ Foster's & 0.814 & 0.242 & 0.618 & 0.752 & 0.616 & 0.601 \\
\hline Aus $\times$ Johnston's & 0.213 & -0.158 & -0.249 & 0.155 & 0.058 & 0.179 \\
\hline Bel $\times$ Stella Artois & 0.093 & 0.111 & 0.678 & 0.397 & 0.249 & 0.242 \\
\hline Bel $\times$ Bouvier & 0.256 & 0.057 & -0.363 & 0.534 & 0.229 & 0.416 \\
\hline Czech $\times$ Budvar & 0.679 & 0.274 & 0.726 & 0.779 & 0.447 & 0.598 \\
\hline Czech $\times$ Karlovy Vari & 0.657 & 0.128 & 0.59 & 0.679 & 0.488 & 0.576 \\
\hline Den $\times$ Carlsberg & 0.412 & -0.155 & 0.086 & 0.556 & 0.479 & 0.51 \\
\hline Den $\times$ Tjaelleborg & 0.021 & 0.525 & 0.533 & 0.403 & 0.253 & 0.263 \\
\hline Ger $\times$ Becks & -0.061 & 0.256 & -0.143 & 0.389 & 0.467 & 0.199 \\
\hline Ger $\times$ Schneider & 0.158 & 0.191 & 0.129 & 0.276 & 0.148 & 0.065 \\
\hline Neth $\times$ Heineken & -0.253 & -0.306 & -0.018 & 0.143 & 0.264 & 0.263 \\
\hline Neth $\times$ Vandemeers & 0.324 & -0.419 & -0.098 & 0.2 & 0.249 & 0.153 \\
\hline UK $\times$ Carling Black Label & 0.79 & 0.649 & 0.655 & 0.673 & 0.5 & 0.52 \\
\hline UK $\times$ Smith's & 0.128 & 0.111 & 0.141 & -0.005 & 0.331 & 0.588 \\
\hline \multicolumn{7}{|l|}{ Sparkling wine } \\
\hline Aus $\times$ Seaview & 0.729 & 0.588 & 0.64 & 0.657 & 0.546 & 0.6 \\
\hline Aus $\times$ Selkins & 0.547 & 0.463 & 0.65 & 0.649 & 0.546 & 0.724 \\
\hline Fra $\times$ Veuve duVernay & 0.441 & 0.215 & 0.427 & 0.536 & 0.43 & 0.247 \\
\hline Fra $\times$ Fabier & 0.515 & 0.39 & 0.308 & 0.502 & 0.328 & 0.317 \\
\hline Ger $\times$ Henkell Trocken & 0.493 & 0.583 & 0.581 & 0.444 & 0.559 & 0.36 \\
\hline Ger $\times$ Gerber & 0.458 & 0.533 & 0.449 & 0.387 & 0.466 & 0.238 \\
\hline Hung Magyarska & 0.73 & 0.516 & 0.687 & 0.592 & 0.672 & 0.695 \\
\hline Italy $\times$ Asti Spumante Martin & ni 0.635 & 0.441 & 0.225 & 0.568 & 0.421 & 0.418 \\
\hline Italy $\times$ Francini & 0.437 & 0.508 & 0.485 & 0.512 & 0.344 & 0.447 \\
\hline Spain $\times$ Freixenet & 0.53 & 0.434 & 0.534 & 0.596 & 0.701 & 0.29 \\
\hline Spain $\times$ Monsanta & 0.759 & 0.485 & 0.483 & 0.689 & 0.577 & 0.294 \\
\hline \multicolumn{7}{|c|}{ Results of sign tests comparing the strength of correlations between the groups } \\
\hline \multirow{3}{*}{\multicolumn{7}{|c|}{$\begin{array}{ll}\text { Lager } & \\
\text { Familiar Brand Names: } & \text { Unfamiliar Brand Names: } \\
\text { Female vs. Male } p=0.1892 & \text { Female vs. Male } p=0.3833\end{array}$}} \\
\hline & & & & & & \\
\hline & & & & & & \\
\hline \multirow{3}{*}{$\begin{array}{l}\text { Sparkling wine } \\
\text { Familiar Brand Names: } \\
\text { Female vs. Male } p=0.3018\end{array}$} & & & & & & \\
\hline & Unfamiliar & Brand $N$ & & & & \\
\hline & Female vs & Male $p=$ & 8145 & & & \\
\hline
\end{tabular}


the case for both lager and sparkling wine and both unfamiliar and familiar brand names. $\mathrm{H} 3$ can therefore be accepted on the basis of this data.

\section{Discussion and Conclusion}

The findings of this study suggest that consumers' age and socio-economic group may affect the extent to which they rely on country of origin in product evaluations of lager and sparkling wine. Consumers' sex does not seem to affect the magnitude of country of origin effects.

Older consumers seem to show stronger country of origin effects than younger consumers. It was proposed, above, that the reason for this might be that older consumers generally rely more on previously formed mental categories in order to compensate for some loss in the ability to process new information, and that they tend to "chunk" information into fewer but broader categories, thus preferring the broader category of country of origin over narrower categories, such as brand name. The present findings seem to fit this proposition,

Alternatively it could also be argued that age-related differences in country of origin effects may not be due to changes in cognition and categorisation strategies but to birth cohort effects (see, for instance, Labouvie-Vief 1976). Older consumers will have grown up with a market in which fewer countries of origin were represented than there are now. It could be that fewer countries of origin mean that product-country images are more clear-cut and easier to use in product evaluations. Thus, older consumers, used to fewer countries of origin and more clear-cut product-country images, might be more willing to rely on country of origin.

While this study cannot give a definitive answer to this question, the finding that age only seemed to have a moderate impact on product-country images may suggest that the first explanation is more helpful. Age-related differences in product-country images would, in all likelihood, be due to birth-cohort effects, based on the assumption that consumers show some preference for countries of origin that were dominant in the market when they first started using the product category. The fact that no such age-related differences in product-country images were found suggests that birth-cohort effects may not be particularly strong in this area. Thus, changes in cognition and categorisation strategy would appear to be the stronger contender for an explanation of the age-related differences found in country of origin effects. However, this is somewhat speculative, and more research should be carried out in this area, in order to come to firmer conclusions.

Socio-economic group was also found to have an influence on the magnitude of country of origin effects. Somewhat unexpectedly the direction of this influence was found to differ between the two products. While, in the case of sparkling wine, respondents of socio-economic groups $\mathrm{AB}$ showed stronger country of origin effects than other groups, in the case of lager, respondents of socio-economic groups $\mathrm{C} 1 \mathrm{C} 2$ showed stronger country of origin effects than $\mathrm{AB}$ respondents.

A possible explanation for this may lie in the extent to which a product is used by different socio-economic groups. It would seem that sparkling wines (particularly if semi-sparkling products, such as Lambrusco, are excluded) are predominantly consumed by people of higher socio-economic status (Retail Business 1994), which means they are probably the more expert consumers of this product. On the other 
hand, lager seems to be more frequently consumed by people of somewhat lower socio-economic status (Key Note Report 1993), making them the more expert consumers of this product. Groups that use the product more often and have more expertise of it may have developed better heuristics to judge a product and may thus be better able, and therefore more likely, to use country of origin in product evaluations. This would fit in with some findings that consumers with higher product knowledge tend to rely more on country of origin (Schaefer 1997).

In conclusion it seems that some demographic variables can have an influence on the magnitude of country of origin effects and that their impact has been unduly neglected in recent research. The findings of this study go some way towards providing a possible explanation for the differences in the magnitude of country of origin effects found in various studies, which have, so far, not been explained satisfactorily.

The findings also suggest that country of origin effects are a fairly complex phenomenon, which may be influenced by various intervening variables, individually and in combination (as, for instance, in the product specific impact of socioeconomic group found in this study). An assumption that country of origin effects are either generally important or generally unimportant, or even that intervening variables have one straight-forward, general impact on the magnitude of country of origin effects would seem over-simplistic.

In practice the findings of this study suggest that companies wishing to market a foreign-made lager or sparkling wine in the UK market should realise that there may be country of origin effects affecting the marketability of their product. When deciding whether or not product-country images are likely to work in the product's favour the marketer needs to take account of the target market's demographic characteristics. For instance, a product with a less than favourable product-country image may still be successful with younger consumers, who seem to attach less importance to country of origin and may thus be more easily swayed by advertising, etc. Similarly it may be possible to market a sparkling wine from a less favourably viewed country to consumers of lower socio-economic groups or a lager with an unfavourable product-country image to consumers of socio-economic groups $A B$, but the introduction of the product may be less successful if the sparkling wine is targeted at $\mathrm{AB}$ consumers or the lager at $\mathrm{C} 1 \mathrm{C} 2$ consumers.

However, stressing a favourable product-country image in advertising may be most successful if aimed at groups that are likely to show country of origin effects for the particular product, for instance older consumers of lager or sparkling wine. In contrast, advertising targeted at groups that are less susceptible to country of origin might be more successful in stressing other product features. Marketers wishing to take account of product-country images and potential country of origin effects in making market entry or advertising decisions would be well advised to study their intended target customers carefully, not only in terms of the productcountry images that they may have, but also with regard to the likely strength of any country of origin effects they may exhibit.

There are various factors that may limit the extent to which we can generalise from the present findings, including the use of a convenience sample, the use of only two product and two extrinsic cues, and a modest sample size. While the found impacts of age and socio-economic group may also apply to other products further research should be carried out before this can be stated with confidence. Such further research 
might suitably look at the impact of the present demographic variables, using other products and possibly a larger number of cues. Different research set ups might also show whether sex may have an impact on country of origin effects under certain circumstances. Larger samples might also help to work out the role of the discussed variables more reliably.

\section{References}

Akaah, I.P. and Atilla, Y. (1993), "Assessing the Influence of Country of Origin on Product Evaluations: An Application of Conjoint Methodology", Journal of International Consumer Marketing, 5, No. 2, pp.39-53.

Baltes, P.B. (1987), "Theoretical Propositions of Life-Span Developmental Psychology: On the Dynamics Between Growth and Decline", Developmental Psychology, 23, pp.611-626.

Baltes, P.B., Dittmann-Kohli, F. and Dixon, R.A. (1984), "New Perspectives on the Development of Intelligence in Adulthood: Toward a Dual-Process Conception and a Model of Selective Optimization with Compensation", In Life-Span Development and Behaviour, (Eds) Baltes, P.B. and Brim, O.G. Jr, San Diego, CA: Academic Press, Vol. 6, pp.33-76.

Bannister, J.P. and Saunders, J.A. (1978), "UK Consumers' Attitudes Towards Imports: The Measurement of National Stereotype Image", European Journal of Marketing, 12, No. 8, pp.562-570.

Bilkey, W.J. and Nes, E. (1982), "Country-of-Origin Effects on Product Evaluations", Journal of International Business Studies, Spring/Summer, pp.89-99.

Birren, J.E., Riegel, K.F. and Morrison, D.F. (1962), "Age Differences in Response Speed as a Function of Controlled Variations of Stimulus Conditions: Evidence of a General Speed Factor", Gerontologia, 6, pp.1-18.

Cattin, P., Jolibert, A. and Lohnes, C. (1982), "A Cross-Cultural Study of 'Made in' Concepts", Journal of International Business Studies, Winter, pp.131-141.

Cicirelli, V.G. (1976), "Categorization Behaviour in Aging Subjects", Journal of Gerontology, 31, pp.676-680.

Cole, C. and Balasubramian, S.K. (1993), "Age Differences in Consumers' Search for Information: Public Policy Implications", Journal of Consumer Research, 10, December, pp.157.

Coleman, R.P. (1983), "The Continuing Significance of Social Class to Marketing", Journal of Consumer Research, 10, December, pp.265-280.

Cordell, V. (1992), "Effects of Consumer Preferences of Foreign Sourced Products", Journal of International Business Studies, 23, No. 2, pp.251-269.

Cox, D.F. (1962), Risk Taking and Information Handling in Consumer Behaviour, Cambridge, MA: Harvard University Press.

Darley, W.K. and Smith, R.E. (1995), "Gender Differences in Information Processing Strategies: An Empirical Test of the Selectivity Model in Advertising Response", Journal of Advertising, 14, No. 1, pp.41-56.

Dornoff, R.J., Tankersley, C.B. and White, G.P. (1974), "Consumers' Perceptions of Imports", Akron Business and Economic Review, 5, Summer, pp.26-29. 
Eroglu, S.A. and Machleit, K.A. (1989), "Effect of Individual and Product-Specific Variables on Utilising Country of Origin as a Product Quality Cue", International Marketing Review, 6, No. 6, pp.27-41.

Ettenson, R. (1993), "Brand Name and Country of Origin Effects in the Emerging Market Economics of Russia, Poland and Hungary", International Marketing Review, 10, No. 5, pp.14-36.

Etzel, M. and Walker, B.J. (1974), "Advertising Strategy of Foreign Products", Journal of Advertising Research, 14, June, pp.41-44.

Fischer, E. and Arnold, S.J. (1994), "Sex, Gender Identity, Gender Role Attitudes, and Consumer Behaviour", Psychology and Marketing, 11, No. 2, pp.163-182.

Gaedecke, R. (1973), "Consumer Attitudes Towards Products 'Made in' Developing Countries", Journal of Retailing, Summer, pp.13-24.

Haas, A. (1979), "Male and Female Spoken Language Differences: Stereotypes and Evidence", Psychological Bulletin, 86, May, pp.616-626.

Halfhill, D.S. (1980), "Multinational Marketing Strategy: Implications of Attitudes Towards Country of Origin", Management International, 20, No. 4, pp.26-30.

Hall, J. (1978), "Gender Effects in Decoding Non-Verbal Cues", Psychological Bulletin, 85, pp.845-875.

Han, C.M. (1989), "Country Image: Halo or Summary Construct?", Journal of Marketing Research, May, pp.222-229.

Johansson, J.K. (1989), "Determinants and Effects of the Use of 'Made in' Labels", International Marketing Review, 6, No. 1, pp.47-58.

Johannson, J.K., Douglas, S.P. and Nonaka, I. (1985), "Assessing the Impact of Country of Origin on Product Evaluations: A New Methodological Perspective", Journal of Marketing Research, 22, November, pp.388-396.

Kaynak, E. and Cavusgil, S.T. (1983), "Consumer Attitudes Towards Products of Foreign Origin: Do they Vary Across Product Classes?", International Journal of Advertising, 2, pp.147-157.

Key Note Report (1993), "Premium Lagers, Beers and Ciders", Market Sector Overview.

Kogan, N. (1974), "Categorization and Conceptualization Styles in Younger and Older Adults", Human Development, 17, pp.218-230.

Labouvie-Vief, G. (1976), "Toward Optimizing Competence in Later Life", Educational Gerontology, 1, pp.75-92.

Lakoff, G. (1987), Women, Fire and Dangerous Things: What Categories Reveal About the Mind, Chicago, London: The University of Chicago Press.

Maccoby, E. and Jacklin, C. (1974), The Psychology of Sex Differences, Stanford: Stanford University Press.

Maheswaran, D. (1994), "Country of Origin as a Stereotype: Effects of Consumer Expertise and Attribute Strength on Product Evaluations", Journal of Consumer Research, 21, No. 2, pp.354-365.

Meyers-Levy, J. (1989), "Gender Differences in Information Processing: A Selectivity Interpretation", In Cognitive and Affective Responses to Advertising, (Eds) Cafferata, P. and Tybout, A.M., Lexington, MA.

Meyers-Levy, J. and Maheswaran, D. (1991), "Exploring Differences in Males' and Females' Processing Strategies", Journal of Consumer Research, 18, June, pp.63-70.

Meyers-Levy, J. and Sternthal, B. (1991), "Gender Differences in the Use of Message Cues and Judgements", Journal of Marketing Research, 28, February, pp.84-96. 
Morganoski, M.A. and Lazarde, M.M. (1987), "Foreign Made Apparel - Influences on Consumers' Perceptions of Brand and Store Quality", International Journal of Advertising, 6, pp.339-346.

Nagashima, A. (1970), "A Comparison of Japanese and U.S. Attitudes Toward Foreign Products", Journal of Marketing, January, pp.68-74.

Nagashima, A. (1977), "A Comparative 'Made in' Product Image Survey Among Japanese Businessmen", Journal of Marketing, 41, July, pp.95-100.

Nes, E. and Bilkey, W.J. (1993), "A Multi-Cue Test of Country-of-Origin Theory", In Product-Country Images: Impact and Role in International Marketing, (Eds) Papadopoulos, N and Heslop, L.A., Binghampton, NY: The Haworth Press Inc, Pp..

O'Brien, S. and Ford, R. (1988), "Can We at Last Say Goodbye to Social Class? An Examination of the Usefulness and Stability of Some Alternative Methods of Measurement", Journal of the Market Research Society, July, pp.289-331.

Okechuku, C. (1994), "The Importance of Product Country of Origin: A Conjoint Analysis of the United States, Canada, Germany and The Netherlands", European Journal of Marketing, 28, No. 4, pp.5-19.

Papadopoulos, N., Heslop, L. and Barmossy, G. (1990), "A Comparative Image Analysis of Domestic versus Imported Products", International Journal of Research in Marketing, 7, No. 4, pp.283-294.

Poole, M.E. (1977), "Social Class - Sex Contrasts in Patterns of cognitive Style", Australian Journal of Education, 21, No. 3, pp.233-255.

Reierson, C. (1966), "Are Foreign Products Seen as National Stereotypes", Journal of Retailing, Fall, pp.33-40.

Retail Business (1994), "Market Surveys", May, No. 435.

Roth, M.S. and Romeo, S.B. (1992), "Matching Product Category and Country Image Perceptions: A Framework for Managing Country of Origin Effects", Journal of International Business Studies, 23, pp.477-497.

Salthouse, T.A. (1985), "Speed of Behaviour and its Implications for Cognition", In Handbook of the Psychology of Aging (2nd Edn.), (Eds) Birren, J.E. and Schaie, K.W., New York: Van Nostrand-Reinhold, pp.400-426.

Salthouse, T.A. (1991), "Cognitive Facets of Aging Well", Generations, 15, No. 1, pp.35-38.

Schaefer, A. (1996), The Impact of Country of Origin on Product Evaluations, unpublished D.Phil. dissertation, University of Buckingham, UK.

Schaefer, A. (1997), "Consumer Knowledge and Country of Origin Effects", European Journal of Marketing, 31, No. 1/2, pp.56-72.

Schaie, K.W. (1977), "Toward a Stage Theory of Adult Cognitive Development", International Journal of Aging and Human Development, 8, pp.129-136.

Schellinck, D.A. (1983), "Cue Choice as a Function of Time Pressure and Perceived Risk", Advances in Consumer Research, 10, pp.470-475.

Schooler, R.D. (1965), "Product Bias in the Central American Common Market", Journal of Marketing Research, November, pp.294-297.

Schooler, R.D. (1971), "Bias Phenomena Attendant to the Marketing of Foreign Goods in the U.S", Journal of International Business Studies, Spring, pp.71-80.

Solomon, M. (1994), Consumer Behaviour (2nd Edn.), Needham Heights, MA: Allyn and Bacon. 
Thorelli, H.B., Lim, J.-S. and Ye, J. (1989), "Relative Importance of Country of Origin, Warranty and Retail Store Image on Product Evaluations", International Marketing Review, 6, No. 1, pp.35-46.

Tse, D. and Gorn, G. (1993), "An Experiment on the Salience of Country of Origin in the Era of Global Brands", Journal of International Marketing, 1, No. 1, pp.57-76.

Usunier, J.-C. (1994), "Social Status and County-of-Origin Preferences", Journal of Marketing Management, 10, pp.765-783.

Wingfield, A., Stine, E.A., Lahar, C.J. and Aberdeen, J.S. (1988), "Does the Capacity of Working Memory Change with Age?", Experimental Aging Research, 14, pp.103-107. 


\section{Appendix - The Questionnaire}

\section{Question 1}

In the following you are given brand names and producer country of fourteen different lagers / sparkling wines. I would like to know your opinion of each of the lagers / sparkling wines, regardless of whether you are familiar with it or not. Therefore your answer can but need not be based on your own experience with the lager / sparkling wine in question. (Please assume that the foreign lagers in the list are actually made in the country stated and then imported into the UK). There are no right or wrong answers, so, please tick the answer that best expresses your personal opinion.

(1) Carlsberg / Freixenet Produce of Denmark / Produce of Spain

a) Please give your opinion of the overall quality of this lager / sparkling wine. The possible answers are between (7) for very good overall quality and (1) for very bad overall quality. [Circle one response only].

very good overall quality $\quad 7654321 \quad$ very bad overall quality

b) If you were serving this lager / sparkling wine to friends or guests, how would this be seen by them?

very trendy - highly acceptable

7654321

not trendy - not at all acceptable

c) Would this lager / sparkling wine, in your opinion, be good value for money or bad value for money?

very good value for money $7654321 \quad$ very bad value for money

Please, judge the brands on the following pages in the same way.

(The question was then repeated for the following brand - country combinations: Lager: Becks, Produce of Germany; Bouvier*, Produce of Belgium; Budvar, Produce of Czechoslovakia; Carling Black Label, Produce of the UK; Vandemeers*, Produce of the Netherlands, Schneiders*, Produce of Germany; Foster's, Produce of Australia; Tjaelleberg*, Produce of Denmark; Karlovy Vari* Produce of Czechoslovakia; Johnston's*, Produce of Australia; Heineken, Produce of the Netherlands; Stella Artois, Produce of Belgium; Smith's*; Produce of the UK. Sparkling Wine: Henkell Trocken, Produce of Germany; Fabier*, Produce of France; Magyarska*, Produce of Hungary; Veuve du Vernay, Produce of France, Francini*, Produce of Italy; Gerber*, Produce of Germany; Seaview, Produce of Australia; Monsanta*, Produce of Spain; Asti Spumante Martini, Produce of Italy; Selkins*, Produce of Australia.) $)^{2}$

${ }^{1}$ There were two separate versions of the questionnaire, relating to lager and sparkling wine respectively. Any one respondent received either the lager or the sparkling wine version. Here both versions are shown together [the relevant aspects of the different versions separated by a slash $(/)$ ] for a better overview. ${ }^{2}$ Brand - country combinations marked with an asterisk * here denote that the brand name was invented. This was, of course, not made obvious to the respondents in the original questionnaires. 
Question $2^{3}$

Please judge the overall quality of lager / sparkling wine produced in the following countries. There are no right or wrong responses, the question asks for your own opinion.

$\begin{array}{llll}\text { Australia / Australia } & \text { very good } & 7654321 & \text { very bad } \\ \text { Netherlands / Spain } & \text { very good } & 7654321 & \begin{array}{l}\text { very bad } \\ \text { velgium / France }\end{array} \\ \begin{array}{l}\text { very good } \\ \text { Czechoslovakia / } \\ \text { Hungary }\end{array} & \begin{array}{l}7654321 \\ \text { very good }\end{array} & 7654321 & \text { very bad } \\ \begin{array}{l}\text { Germany / } \\ \text { Germany }\end{array} & \text { very good } & 7654321 & \text { very bad } \\ \begin{array}{l}\text { Denmark / Italy } \\ \text { The UK }\end{array} & \text { very good } & 7654321 & \text { very bad } \\ & \text { very good } & 7654321 & \text { very bad }\end{array}$

[This question was repeated for the dimensions 'value for money' and 'trendiness' - social acceptability.]

\section{Question 3}

For statistical reasons I would like you to give me some information about yourself.

a) Please tick your age group from the list below.

$$
\begin{aligned}
& \square 18 \text { to } 24 \\
& \square 25 \text { to } 34 \\
& \square 35 \text { to } 54 \\
& \square 55 \text { or over }
\end{aligned}
$$

b) Please write down your occupation.

If it is not you, please write down the occupation of the main wage earner in your household.

c) Are you $\square$ female $\quad$ or $\square$ male?

\footnotetext{
${ }^{3}$ In the original questionnaire this question did not follow directly after the previous one, but was separate by another question.
} 